\title{
Enhancing Phycoerythrin and Phycocyanin Production from Porphyridium cruentum CCALA 415 in Synthetic Wastewater: The Application of Theoretical Methods on Microalgae
}

\author{
Melih ONAY*1(D) \\ ${ }^{1}$ Van Yuzuncu Yil University, Faculty of Engineering, Department of Environmental Engineering, 65080, Van, \\ Turkey
}

(Alınış / Received: 25.12.2020, Kabul / Accepted: 19.08.2021, Online Yayınlanma / Published Online: 25.12.2021)

\author{
Anahtar Kelimeler \\ Phycoerythrin, \\ Phycocyanin, \\ Porphyridium cruentum, \\ RSM-CCD, \\ rstool
}

\begin{abstract}
Phycoerythrin (PE) and phycocyanin (PC) are florescent pigments. They have the colorant role in the industry. In this study, production of PE and PC from Porphyridium cruentum were investigated at the various conditions such as different concentrations of municipal wastewater, wavelengths and salicylic acid using Response Surface Methodology-Central Composite Design (RSM-CCD), regression analysis and rstool models. The maximum RSM predicted PE concentration was $29.5 \mathrm{mg} / \mathrm{g}$ biomass at $50 \%$ of wastewater, $510 \mathrm{~nm}$ of wavelength and $10 \mu \mathrm{M}$ of salicylic acid. On the other hand, maximum RSM predicted PC concentration was $6.9 \mathrm{mg} / \mathrm{g}$ biomass at $50 \%$ of wastewater, $680 \mathrm{~nm}$ and $40 \mu \mathrm{M}$ of salicylic acid. According to the ANOVA results, the square effects of the three variables $\left(\mathrm{X}_{1}, \mathrm{X}_{2}\right.$ and $\mathrm{X}_{3}$ ) were found to be significant for the phycocyanin concentration, while the wastewater and salicylic acid variables $\left(\mathrm{X}_{1}\right.$ and $\left.\mathrm{X}_{3}\right)$ were found to be important in the Phycoerythrin concentration. In addition to this, the highest PE and PC concentrations were 27.648 and $5.7104 \mathrm{mg} / \mathrm{g}$ biomass, respectively, for $50 \%$ of wastewater, $512.5 \mathrm{~nm}$ and $47.0833 \mu \mathrm{M}$ of salicylic acid according to rstool model. In conclusion, the variables such as wastewater, wavelength and salicylic acid can be used for the highest PE and PC concentration by means of RSM-CCD and rstool models and these variables may contribute to the industrial production of the two pigments.
\end{abstract}

\section{Sentetik Atıksuda Porphyridium cruentum CCALA 415'den Fikoeritrin ve Fikosiyanin Üretiminin Arttırılması: Mikroalglere Teorik Metotların Uygulanması}

Keywords

Fikoeritrin,

Fikosiyanin,

Porphyridium cruentum, CYM-MTT, rstool
Özet: Fikoeritrin (FE) ve fikosiyanin (FS) floresan pigmentlerdir. Bu pigmentler sanayide boyar madde olarak kullanılırlar. Bu çalışmada, evsel atıksuyu, dalga boyu ve salisilik asidin çeşitli konsantrasyonlarında büyütülen Porphyridium cruentum'dan üretildi. FE ve FS konsantrasyonu Cevap Yüzey Metodu-Merkezi Tümleşik Tasarımı (CYM-MTT), regresyon analizi ve rstool modeller aracılığı ile incelendi. Cevap Yüzey Metodu ile tahmin edilen maksimum FE konsantrasyonu, \% 50 atıksu, $510 \mathrm{~nm}$ dalga boyunda ve $10 \mu \mathrm{M}$ salisilik asit konsantrasyonunda 29,5 $\mathrm{mg} / \mathrm{g}$ biyokütle idi. Diğer taraftan, Cevap Yüzey Metodu ile tahmin edilen maksimum FS konsantrasyonu, \% 50 atıksu, $680 \mathrm{~nm}$ dalga boyunda ve $40 \mu \mathrm{M}$ salisilik asit konsantrasyonunda $6,9 \mathrm{mg} / \mathrm{g}$ biyokütle idi. ANOVA sonuçlarına göre, fikosiyanin konsatrasyonu için üç değişkenin kare etkileri önemli bulunurken, fikoeritrinin konsantrasyonunda atık su ve salisilik asit değişkenleri önemli bulunmuştur. Buna ek olarak, rstool aracılı̆ıı ile FE ve FS konsantrasyonları \% 50 atıksu, $512,5 \mathrm{~nm}$ dalga boyunda ve $47,0833 \mu \mathrm{M}$ salisilik asit konsantrasyonunda sırası ile 27,648 ve $5,7104 \mathrm{mg} / \mathrm{g}$ biyokütle idi. Sonuç olarak, atıksu, dalga boyu ve salisilik asit gibi değişkenler Cevap Yüzey Metodu-Merkezi Tümleşik Tasarım (CYM-MTT) ve rstool modeller ile en yüksek FE ve FS konsantrasyonu için kullanılabilir. $\mathrm{Bu}$ değişkenler, iki pigmentin sanayide üretimine katkıda bulunabilir. 


\section{Introduction}

Microalgae are photosynthetic microorganisms and have some advantages compared to other organisms. They have higher lipid, carbohydrate and protein content than plants in the extreme environmental conditions. Microalgae can produce bioactive compounds such as flavonoid, flavones and flavonols. Porphyridium cruentum is a eukaryotic unicellular red microalgae belonging to the Rhodophyta phylum. They don't have cell wall and often can be cultivated into artificial seawaters such as f/2 and ASW [1, 2]. In addition, they have various concentrations of carotenoid, chlorophyll and other pigments. These molecules can be used in a wide range of food, cosmetics and medical industry [3].

Phycobiliproteins are located in phycobilisomes. Phycobiliproteins are light harvesting pigments in red algae. They absorb light and energy migrates to the photosystems. They increase absorption while they are subjected to metabolic factors as high $\mathrm{pH}$ and ionic strength [4]. Phycobiliproteins have the bilins giving a fluorescent property. This maintains chromophore property to phycobiliproteins. They can be classified into two categories: phycoerythrin (PE) and phycocyanin (PC) [5].

Porphyridium cruentum has fluorescent pigments such as PE and PC [6]. PE has a red color and photosynthetic pigment. It is water soluble pigment and has nonstable structure in food industry. High amounts of light affect it adversely. Light leads to its unstable formation. However, PE has been used for antioxidant, anti-inflammatory, anti-cancer and food studies due to its intense red color [7]. Similarly, PC has an intense blue color and it is a natural blue dye for food and cosmetics industry [8]. It has been used for photodynamic therapy as photosensitizer in tumor therapy. Also, it has anti-inflammatory and cancer effect for medicine treatment.

Purification of PE and PC is a difficult process. Yields of them generally can be reduced by means of complex purification methods such as chromatographic techniques. Membrane technology is a useful technique for their purifications. Yield especially has been increased by hydrophilic PVDF membranes [9]. Phycocyanin can be affected by high heat and light. They can lose blue color at above $45^{\circ} \mathrm{C}$. This situation causes the formation of unstable structure and PC can decay fast with temperature [10]. In addition, antioxidant properties of PE and PC are important for metabolism studies. Reactive oxygen species affects metabolism and they lead to the formation of free radicals. Phytochemicals such as $\mathrm{PE}$ and $\mathrm{PC}$ can neutralize the effects of free radicals and diminish oxidative stress levels in the metabolism. PE and PC are known as non-enzymatic antioxidant due to their effectiveness in oxidative stress [11].
Wastewater treatment is a significant issue for reuse of water and to provide healthy water. Also, examination of the problems related with wastewater treatment facilities and wetlands contributes to the solution of the problems. [12]. Microalgae generally grow in special media and wastewater. Microalgae in wastewater can be used for different goals. For instance, these wastewaters can include micropollutants such as erythromycin, galaxolide, ibuprofen and estrone. These micro-pollutants can be removed by microalgae [13]. In addition, wastewaters have organic and inorganic molecules such as urea, glucose, $\mathrm{C}, \mathrm{N}, \mathrm{P}$ and $\mathrm{S}$. These molecules maintain nutrients for microalgae and microalgae grow. In return, micropollutants are removed from wastewaters $[13,14]$.

Various pigments with high value products can be produced in wastewater by microalgae. One of them, carotenoids, can be produced in urban wastewater effectively [15]. Microalgae can metabolize inorganic or organic molecules and convert energy from sun to chemical or from nutrients into ATP. Autotrophic microalgae use inorganic carbon such as carbon dioxide in the availability of light and form biomass. Unlike, heterotrophic microalgae use organic carbon such as acetate and glucose for biomass production [16]. These compounds can be found in wastewater in excess and provide the growth of microalgae. Microalgae can be cultivated in open pond and photobioreactors. Open ponds are cheaper than photobioreactors but they are significantly more susceptible to culture contamination [17]. Open ponds provide high amounts of biomass. They use sunlight for cultivation but light effectively cannot reach the depths of ponds. On the other hand, photo-bioreactors can be operated at the desired light intensity and wavelength. Optimum conditions can be determined by controlling the whole system. But, their limitation is that they work on a laboratory scale $[17,18]$.

Microalgae generally are cultivated in flat or tubular photo-bioreactors. Flat photo-bioreactors can be adjusted for modular design and have high amounts of light penetration. They have lower dissolved oxygen levels. One of the main drawbacks of flat photobioreactors is the difficulty of temperature control. In this system, algal biofilm formation can be observed but this problem can be overcome by mixing the system. Tubular photo-bioreactors can be used for outdoor systems and have higher biomass productivity. But, productivity can change according to algal strains. This system is cheaper than flat system. However, tubular photo-bioreactors have higher dissolved oxygen levels. They form inconvenient $\mathrm{pH}$ and carbon dioxide gradient. Fouling is higher in reactors.

Photo-inhibition can often be observed [18]. Light intensity is important for the growth of algal cells. It has effects on photosynthesis system, intermediary metabolism of microalgae and components of culture. 
Photosynthesis can be enhanced by the presence of suitable light sources such as LED or fluorescent light and lamp and light intensities [19]. This effect can be positive or negative $[20,21]$. Each microalgae species contains different pigments and they can be maximally absorbed at various wavelengths. This situation forms different biomass concentration, metabolic content and pigment concentrations [22].

Response surface methodology (RSM) is the technique that independent factors and their interactions can be estimated for the minimization of experimental errors. RSM generally is used with central composite design (CCD). This method depends on experimental data and regression analysis. It provides time saving for experimental studies [23]. The rstool maintains an interface tool for searching one-dimensional contours of multidimensional response surface models. Nowadays, biofuel production, wastewater treatment, biomass production and harvesting method for microalgae have been studied at various conditions by RSM-CCD and rstool [24-26]. The objective of this study was to investigate phycoerythrin and phycocyanin contents using RSM-CCD, regression analysis and rstool in Porphyridium cruentum CCALA 415 grown in the various conditions such as different concentrations of municipal wastewater and salicylic acid and wavelengths and these variables will contribute to PE and PC concentrations for industry.

\section{Material and Method}

\subsection{Cultivation of Porphyridium cruentum CCALA 415}

Porphyridium cruentum CCALA 415 was obtained from Culture Collection of Autotrophic Organisms (CCALA) in Czechia. Porphyridium cruentum was grown in ASW medium [27] and municipal wastewater was prepared according to Zouboulis $[28,29]$. BOD, COD, TOC, $\mathrm{PO}_{4}^{-3}$ and $\mathrm{NH}_{4}{ }^{+}$values were $980 \mathrm{mg} / \mathrm{L}, 1943 \mathrm{mg} / \mathrm{L}, 729$ $\mathrm{mg} / \mathrm{L}, 61 \mathrm{mg} / \mathrm{L}$ and $189 \mathrm{mg} / \mathrm{L}$, respectively. Municipal wastewater was enriched with artificial seawater like ASW medium to maintain same ionic strength in the medium. Then, different concentrations of wastewater $(25,50,75$ and $100 \%)$ were combined with ASW medium. ASW medium solely was used as control. Samples were grown at $22^{\circ} \mathrm{C}, 75 \mu \mathrm{molm}^{-2} \mathrm{~s}^{-1}$ and 16:8 (L:D). Firstly, the samples were incubated in $125 \mathrm{~mL}$ of working volume in $250 \mathrm{~mL}$ of flask. Then, microalgae samples were transferred from flask into flat photobioreactor (FPBR) (1L) and the details related with FPBR were given at previous study [30].

\subsection{Growth rate and harvesting of Porphyridium cruentum CCALA 415}

Porphyridium cruentum CCALA 415 was counted by using a hemocytometer at stationary phase. Then, Porphyridium cruentum CCALA 415 was harvested by centrifugation at $6500 \mathrm{rpm}$ for $10 \mathrm{~min}$. The pellet samples were washed with distilled water and dried. The samples were stored at $-20^{\circ} \mathrm{C}$ for further studies.

\subsection{Extraction and analysis of phycoerythrin and phycocyanin}

Phycobiliproteins were extracted according to Coward with a few modifications [31]. 1mg of dried microalgae samples were mixed with $2 \mathrm{~mL}$ of phosphate buffer $(0.1 \mathrm{M})$ at $\mathrm{pH}$ 6.6. Then, samples were left at $-20^{\circ} \mathrm{C}$ for $8 \mathrm{~h}$. After this period, samples were homogenized and vortexed for $6 \mathrm{~min}$. Microalgae were refrozen and extracted for 4 times. Finally, samples were centrifuged at $11200 \mathrm{rcf}$ for $4 \mathrm{~min}$. Supernatant samples were taken and measured at 455, 564, 592, 618 and 645nm for phycoerythrin (PE) and phycocyanin (PC) concentrations according to Beer [32].

$\mathrm{PE}(\mathrm{mg} / \mathrm{mL})=\left[\left(\mathrm{OD}_{564}-\mathrm{OD}_{592}\right)-\left(\mathrm{OD}_{455}-\mathrm{OD}_{592}\right) \times 0.2\right]$ $\mathrm{x} 0.12$

$\mathrm{PC}(\mathrm{mg} / \mathrm{mL})=\left[\left(\mathrm{OD}_{618}-\mathrm{OD}_{645}\right)-\left(\mathrm{OD}_{592}-\mathrm{OD}_{645}\right) \mathrm{x}\right.$ $0.51] \times 0.15$

\subsection{Application of response surface methodology (RSM)}

The central composite design (CCD) was used to design experimental matrix for RSM. CCD is a practical method to carry out the concentrations of phycobiliproteins (PE and PC) under various medium conditions and their interactions with each other. In current study, wastewater (X1), wavelength (X2) and salicylic acid (X3) were defined as -1 (low), 0 (central point), and +1 (high). The concentrations of phycobiliproteins were calculated according to second-order polynomial equation. This equation was given below.

$$
Y=\beta_{\circ}+\sum_{i=1}^{n} \beta_{i} X_{i}+\sum_{i=1}^{n} \beta_{i i} X_{i}^{2}+\sum \sum_{i<j=1}^{n} \beta_{i j} X_{i} X_{j}
$$

The reactants used in this study were given in Table 1.

Table 1. The reactants used and levels for the determination of the concentrations of phycobiliproteins (PE and PC)

\begin{tabular}{cccccc}
\hline Reactants & $\mathbf{- 2}$ & $\mathbf{- 1}$ & $\mathbf{0}$ & $\mathbf{1}$ & $\mathbf{2}$ \\
\hline X1: Wastewater & 0 & 25 & 50 & 75 & 100 \\
concentration $(\mathrm{v} / \mathrm{v} \%)$ & & & & & \\
X2: Wavelength $(\mathrm{nm})$ & 400 & 440 & 510 & 580 & 680 \\
X3: Salicylic Acid $(\mu \mathrm{M})$ & 10 & 20 & 40 & 80 & 160 \\
\hline
\end{tabular}

\subsection{Analysis of variance}

ANOVA was applied for applicability of response surface methodology. When $P$ value is less than 0.05 , the accuracy of model was significant. Degrees of freedom (DF), sum of squares (SS), mean square (MS), $F$ and $P$ values (probability) and $t$-values were evaluated for the validation of the model. 


\subsection{The application of interactive response surface modeling}

In this study, rstool in MATLAB was used. rstool maintains an interface tool for searching onedimensional contours of multidimensional response surface models and it is used to fit calibration data. rstool draws a 95\% synchronous confidence line for the adjusted response surface.

\section{Results and Discussion}

3.1. The importance of reactants on phycoerythrin (PE) concentrations by means of response surface methodology

In this study, the effects of wastewater concentration (v/v \%) (X1), wavelength (nm) (X2) and salicylic Acid $(\mu \mathrm{M})(\mathrm{X} 3)$ on phycoerythrin (PE) concentrations were carried out. Maximum concentrations of phycobiliproteins were calculated by response surface methodology. Two second order polynomial equations were written to calibrate PE concentrations under various parameters. This equation was given below.

$$
\begin{aligned}
& Y_{1}=19.768+0.17172 X_{1}+0.037373 X_{2}+ \\
& 0.00029953 X_{3}+2.8571 \times 10^{-5} X_{1} X_{2}-2.0526 \times 10^{-} \\
& { }^{4} X_{1} X_{3}-1.0525 \times 10^{-4} X_{2} X_{3}-1.6456 \times 10^{-3} X_{1}^{2}- \\
& 5.3357 \times 10^{-5} X_{2}^{2}-2.4576 \times 10^{-4} X_{3}^{2}
\end{aligned}
$$

Also, CCD of RSM for the maximum PE concentration was given in Table 2 .

Experimental and RSM predicted PE concentrations were compared. The maximum experimental PE concentration was $30.3 \mathrm{mg} / \mathrm{g}$ biomass at $50 \%$ of wastewater, $510 \mathrm{~nm}$ of wavelength and $10 \mu \mathrm{M}$ of salicylic acid. Similarly, RSM predicted PE concentration was $29.5 \mathrm{mg} / \mathrm{g}$ biomass. Conversely, while the lowest PE concentration was $22.8 \mathrm{mg} / \mathrm{g}$ biomass at $0 \%$ of wastewater, $510 \mathrm{~nm}$ of wavelength and $40 \mu \mathrm{M}$ of salicylic acid for the experimental results, $\mathrm{PE}$ concentration was $23.1 \mathrm{mg} / \mathrm{g}$ biomass at 50 $\%$ of wastewater, $680 \mathrm{~nm}$ of wavelength and $40 \mu \mathrm{M}$ of salicylic acid for RSM predicted PE concentration. 3D RSP and 2D contour plots related with wastewater concentration (v/v \%) (X1) and wavelength (nm) (X2) were given in Figure 1. These figures explain how $\mathrm{X}_{1}$ and $\mathrm{X}_{2}$ affect $\mathrm{PE}$ concentrations. While $\mathrm{X}_{1}$ concentration was increasing from -2 degree to zero level, PE concentration had higher value than the others. While $\mathrm{X}_{2}$ value increased from -2 to -1 level, $\mathrm{PE}$ concentration had higher value. On the other hand, from - 1 to zero level, PE concentration decreased.

The interaction between $X_{1}$ and $X_{3}$ was shown in Figure 2. Irregular shape of plot proves important interactions between $\mathrm{X}_{1}$ and $\mathrm{X}_{3}$. From 0 to 2 levels, when $X_{1}$ and $X_{3}$ valued raised, $P E$ concentration drastically decreased. Similarly, the interaction between $X_{2}$ and $X_{3}$ was given in Figure 3. Between $X_{2}$ and $X_{3}$, interaction partially was shown. When $X_{2}$ and $\mathrm{X}_{3}$ increased from -1 to 2 , $\mathrm{PE}$ concentration significantly decreased. We summarize the results of $\mathrm{PE}$ concentrations that $\mathrm{PE}$ concentration decreased at the high concentrations of the variables. Probably, stress factors adversely affected PE concentration under these variables. In addition, while PE concentration increased in the short wavelengths such

\begin{tabular}{|c|c|c|c|c|c|}
\hline Run No. & $\begin{array}{l}\text { Wastewater concentration } \\
(\mathrm{X} 1)(\mathrm{v} / \mathrm{v} \%)\end{array}$ & $\begin{array}{l}\text { Wavelength } \\
\text { (X2) (nm) }\end{array}$ & $\begin{array}{l}\text { Salicylic Acid } \\
(\mathrm{X} 3)(\mu \mathrm{M})\end{array}$ & $\begin{array}{l}\text { Experimental } \\
\text { (PE) } \mathrm{mg} / \mathrm{g}\end{array}$ & $\begin{array}{c}\text { RSM } \\
\text { Predicted (PE) } \mathrm{mg} / \mathrm{g}\end{array}$ \\
\hline 1. & 25 & 440 & 20 & 29.4 & 28.5 \\
\hline 2. & 25 & 440 & 80 & 27.6 & 26.9 \\
\hline 3. & 25 & 580 & 20 & 25.3 & 26.0 \\
\hline 4. & 25 & 580 & 80 & 23.3 & 23.5 \\
\hline 5. & 75 & 440 & 20 & 29.6 & 29.3 \\
\hline 6. & 75 & 440 & 80 & 27.4 & 27.1 \\
\hline 7. & 75 & 580 & 20 & 25.6 & 26.9 \\
\hline 8. & 75 & 580 & 80 & 23.4 & 23.8 \\
\hline 9. & 0 & 510 & 40 & 22.8 & 23.2 \\
\hline 10. & 100 & 510 & 40 & 25.1 & 24.6 \\
\hline 11. & 50 & 400 & 40 & 27.8 & 29.5 \\
\hline 12. & 50 & 680 & 40 & 23.9 & 23.1 \\
\hline 13. & 50 & 510 & 10 & 30.3 & 29.5 \\
\hline 14. & 50 & 510 & 160 & 26.2 & 26.3 \\
\hline 15. & 50 & 510 & 40 & 28.1 & 28.0 \\
\hline 16. & 50 & 510 & 40 & 27.9 & 28.0 \\
\hline 17. & 50 & 510 & 40 & 28.2 & 28.0 \\
\hline 18. & 50 & 510 & 40 & 27.9 & 28.0 \\
\hline 19. & 50 & 510 & 40 & 28.0 & 28.0 \\
\hline 20. & 50 & 510 & 40 & 28.1 & 28.0 \\
\hline 21. & 50 & 510 & 40 & 28.2 & 28.0 \\
\hline 22. & 50 & 510 & 40 & 28.1 & 28.0 \\
\hline 23. & 50 & 510 & 40 & 28.0 & 28.0 \\
\hline 24. & 50 & 510 & 40 & 28.1 & 28.0 \\
\hline
\end{tabular}
as purple and blue, it decreased in the long wavelengths such as yellow and red.

Table 2. CCD of RSM for the maximum phycoerythrin concentration 

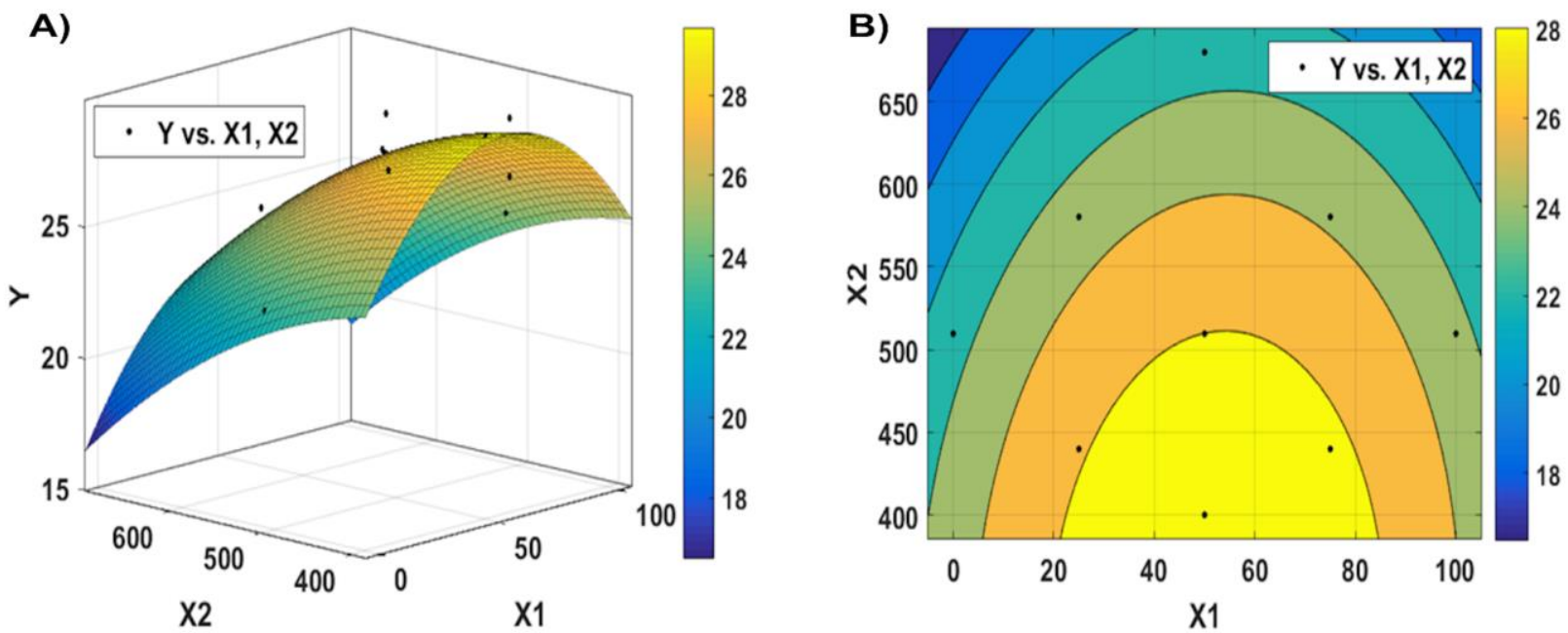

Figure 1. 3D RSM and 2D CPs for interaction effect of (A-B) wastewater concentration (v/v \%) (X1) and wavelength (nm) (X2) for PE concentration.
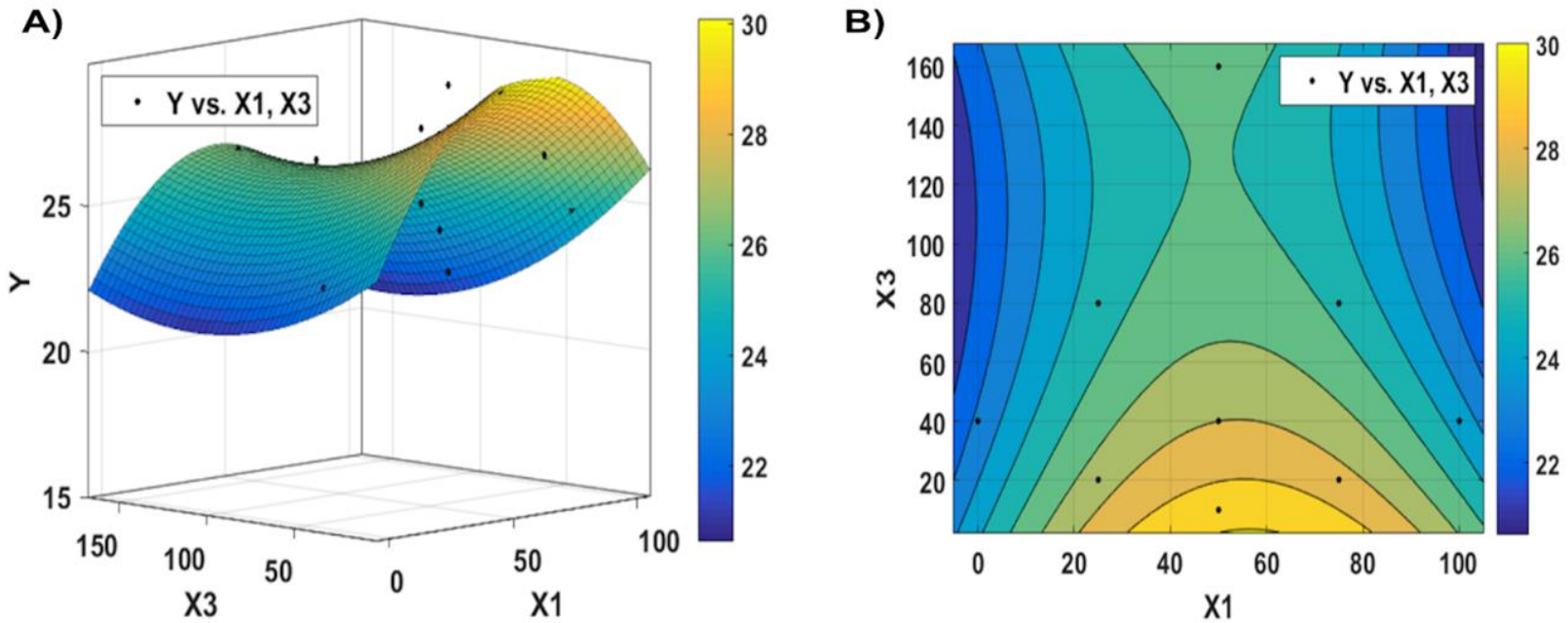

Figure 2. 3D RSM and 2D CPs for interaction effect of (A-B) wastewater concentration (v/v \%) (X1) and salicylic acid ( $\mu M)$ (X3) for PE concentration.

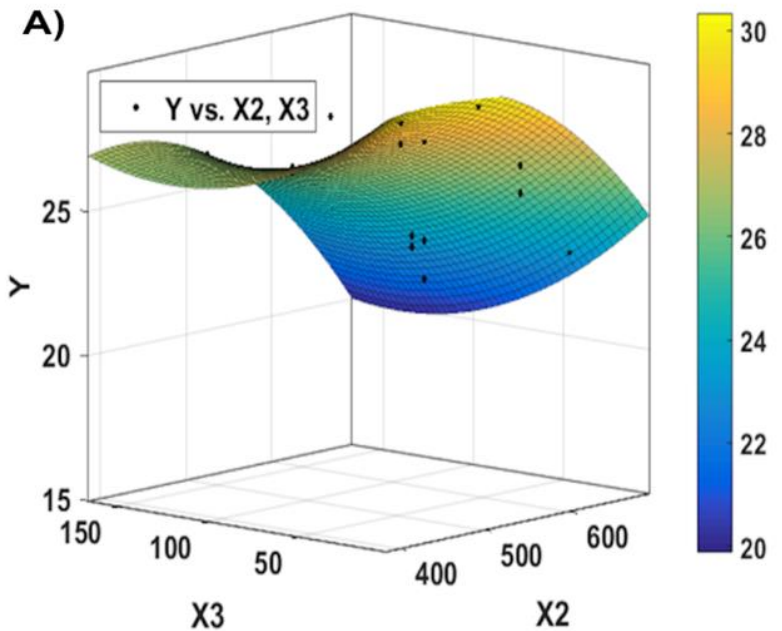

B)

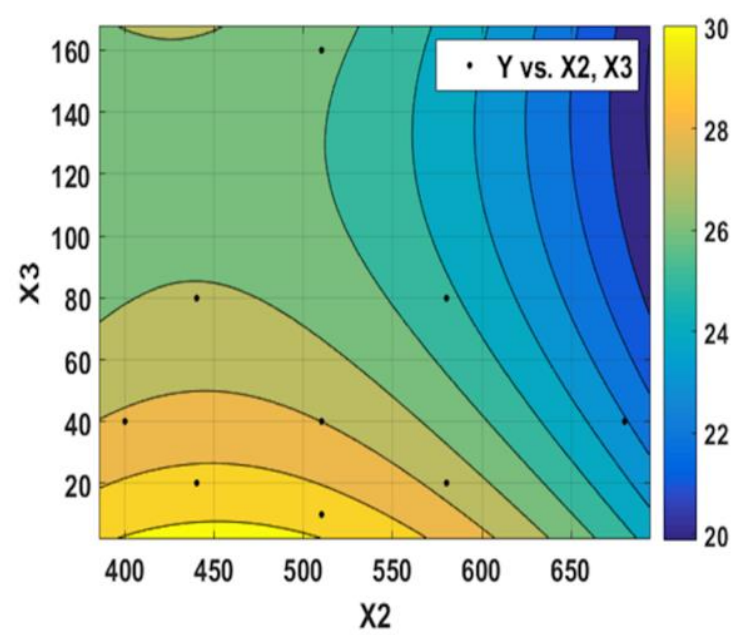

Figure 3. 3D RSM and 2D CPs for interaction effect of (A-B) wavelength (nm) (X2) and salicylic Acid ( $\mu M)(X 3)$ for PE concentration.

In the literature, there are many studies related with PE extraction under different conditions. Mishra et al. carried out PE concentration from Pseudanabaena sp. isolated in India under various color lights. These bacterial cyanobacteria showed different behaviors in white, blue and green light. The maximum PE 
concentration was $39.2 \mathrm{mg} / \mathrm{mL}$ and $32.2 \mathrm{mg} / \mathrm{mL}$ for green and blue light. These results are compatible with our ones. Also, they researched the biomass concentrations. The maximum biomass concentration was $0.94 \mathrm{~g} / \mathrm{L}$ in the blue light [33]. PE extraction from Palmaria palmate was investigated with response surface methodology. In this study, enzymatic digestion procedure was modelled. The extraction yield had 62 times higher with enzymatic procedure than non-enzymatic one. Also, the PE purification with enzyme increased 16 times compared to nonenzymatic procedure [34]. Pereira et al. examined maceration, ultrasound-assisted, high pressureassisted, and freeze-thaw extraction using RSM. The maximum PE yield was found as $3.6 \mathrm{mg} \mathrm{PE} / \mathrm{g}$ biomass for $10 \mathrm{~min}$ of treatment time, $0.1 \mathrm{M}$ buffer concentration and biomass: buffer ratio (1:50) [35].

Porphyridium marinum was carried out at the various concentrations of $\mathrm{NaNO}_{3}, \mathrm{~K}_{2} \mathrm{HPO}_{4}$ and trace elements. Box-Behnken model had the highest PE concentration $(40 \mathrm{mg} / \mathrm{g})$ at $3.4 \mathrm{~g} / \mathrm{L}$ of $\mathrm{NaNO}_{3}$, lack of $\mathrm{K}_{2} \mathrm{HPO}_{4}$ and 70 $\mu \mathrm{mol}$ photons $/ \mathrm{m}^{2} / \mathrm{s}$ of light intensity [36]. Mittal and Raghavarao focused on the extraction of PE by Gelidium pusillum. Enzymatic hydrolysis process was found as the best alternative method. In this method, cellulase provided $26 \%$ of an increase in biomass rate [37].

In another study, pulsed electric field treatments were applied for maximum PE concentration on Porphyridium cruentum. The maximum PE concentration was $32 \mathrm{mg} / \mathrm{g}$ at $10 \mathrm{kV} / \mathrm{cm}$ for $150 \mu \mathrm{s}$ after $24 \mathrm{~h}$ of incubation [38].
Munier studied on the instability of PE. Grateloupia turuturu and Porphyridium cruentum was exposed to various time durations. At the end of $48 \mathrm{~h}, \mathrm{PE}$ concentration decreased by nearly $30 \%$ [39].

Zhao et al. researched the purification of PE from Gracilaria tenuistipitata by means of agar extraction method. Yield was $30.3 \mu \mathrm{g} / \mathrm{g}$ R-PE. This value was equal to much more than 4 of purification ratio [40].

In addition, PE can be used for various goals. Afreen and Fatma investigated that PE isolation and purification from Michrochaete can be achieved. They also studied antioxidant, antibacterial, antifungal and anticancer potential of PE. PE had higher antioxidant activity $(0.023 \mathrm{mg} / \mathrm{mL})$ with ABTS than other methods such as DPPH $(0.043 \mathrm{mg} / \mathrm{mL})$ and SOR $(0.553$ $\mathrm{mg} / \mathrm{mL}$ ). Moreover, PE displayed anticancer activity against HepG2 cells (105 $\mu \mathrm{g} / \mathrm{mL})$ [41].

\subsection{ANOVA results for estimated coefficients and quadratic model of phycoerythrin concentration}

We analyzed ANOVA values such as degrees of freedom (DF), sum of squares (SS), mean square (MS), $F$ and $P$ values (probability) for PE concentration. $F$ value was 16.2561 and $P$-value was $<0.0001$. These results indicate that all system terms are important for PE concentration. All ANOVA results were given in Table 3.

ANOVA results for estimated coefficients of the quadratic model of PE concentration were calculated. tand $p$ values for intercept were 1.9807 and 0.067619 , respectively. $\mathrm{t}$ and $\mathrm{p}$ values were 1.9925 and

Table 3. ANOVA for quadratic model of phycoerythrin concentration

\begin{tabular}{lcccccc}
\hline \multicolumn{1}{c}{ Source } & \multicolumn{5}{c}{ Phycoerythrin Concentration (mg/g biomass ) } \\
\hline Model & Df a & SS $^{\mathbf{b}}$ & MSc $^{\mathbf{c}}$ & F-value & P-value & Significance \\
Residual & 9.0000 & 90.2684 & 10.0298 & 16.2561 & $<0.0001$ \\
Total & 14.0000 & 8.6378 & 0.6170 & & \\
\end{tabular}

aDegree of freedom for each term

bSum of Square for the regression model

cMean Squared error for each term

Table 4. ANOVA for estimated coefficients of the quadratic model of phycoerythrin concentration

\begin{tabular}{|c|c|c|c|c|c|}
\hline \multicolumn{6}{|c|}{ Phycoerythrin concentration (mg/g biomass) } \\
\hline Source & Coefficient & StdErra & t valueb & P value & Significance \\
\hline (Intercept) & 19.768 & 9.9804 & 1.9807 & 0.067619 & \\
\hline $\mathrm{X}_{1}$ & 0.17172 & 0.086187 & 1.9925 & 0.066192 & \\
\hline $\mathrm{X}_{2}$ & 0.037373 & 0.032914 & 1.1355 & 0.27525 & \\
\hline $\mathrm{X}_{3}$ & 0.00029953 & 0.070748 & 0.0042338 & 0.99668 & \\
\hline $\mathrm{X}_{1} \mathrm{X}_{2}$ & $2.8571 \times 10^{-5}$ & $1.5869 \times 10^{-4}$ & 0.18004 & 0.8597 & \\
\hline $\mathrm{X}_{1} \mathrm{X}_{3}$ & $-2.0526 \times 10^{-4}$ & $3.6041 \times 10^{-4}$ & -0.56953 & 0.57802 & \\
\hline $\mathrm{X}_{2} \mathrm{X}_{3}$ & $-1.0525 \times 10^{-4}$ & $1.2928 \times 10^{-4}$ & -0.81412 & 0.4292 & \\
\hline $\mathrm{X}_{1} \mathrm{X}_{1}$ & $-1.6456 \times 10^{-3}$ & $2.3524 \times 10^{-4}$ & -6.9954 & 0.0000062941 & Very significant \\
\hline $\mathrm{X}_{2} \mathrm{X}_{2}$ & $-5.3357 \times 10^{-5}$ & $2.8935 \times 10^{-5}$ & -1.844 & 0.086442 & \\
\hline $\mathrm{X}_{3} \mathrm{X}_{3}$ & $-2.4576 \times 10^{-4}$ & $1.0636 \times 10^{-4}$ & 2.3106 & 0.036604 & Significant \\
\hline
\end{tabular}

Results is significant when $\mathrm{P}<0.05 \mathrm{R}^{2}=0.91, \mathrm{R}^{2}(\mathrm{adj})=0.86, \mathrm{MSE}=0.62$

aStandard error of the coefficients

$\mathrm{b} t$-statistic for each coefficient to test the null hypothesis

${ }^{c} p$-value for the $t$-statistic of the hypothesis test 
$0.066192 ; 1.1355$ and 0.27525 ; and 0.0042338 and 0.99668 for wastewater, wavelength and salicylic acid, respectively. According to these results, every reactant alone does not have a significant effect for higher PE concentration. In addition, according to ANOVA results, the interactions among reactants showed similar results and they don't have interactions. However, squared effects of wastewater and salicylic acid were very significant for PE concentration. This result demonstrated that wastewater and salicylic acid affect highly PE concentration. ANOVA for estimated coefficients of the quadratic model of PE concentration were given in Table 4.

\subsection{The effects of reactants on phycocyanin (PC) concentrations by using response surface methodology}

The effects of wastewater concentration (v/v \%) (X1), wavelength $(\mathrm{nm})(\mathrm{X} 2)$ and salicylic Acid $(\mu \mathrm{M})(\mathrm{X} 3)$ on phycocyanin $(\mathrm{PC})$ concentrations were examined. The maximum concentrations of PC were calculated by response surface methodology. Two second order polynomial equations were written to estimate PC concentrations under various parameters. This equation was given below.

$$
\begin{aligned}
& Y_{2}=-1.1573+0.032062 \mathrm{X}_{1}+0.017459 \mathrm{X}_{2}- \\
& 0.0074868 \mathrm{X}_{3}-1.4286 \times 10^{-5} \mathrm{X}_{1} \mathrm{X}_{2}+2.1053 \times 10^{-} \\
& { }^{5} \mathrm{X}_{1} \mathrm{X}_{3}-1.4085 \times 10^{-5} \mathrm{X}_{2} \mathrm{X}_{3}-2.5723 \times 10^{-4} X_{1}^{2}- \\
& 8.1803 \times 10^{-6} \mathrm{X}_{2}^{2}-5.306 \times 10^{-5} \mathrm{X}_{3}^{2}
\end{aligned}
$$

In this study, experimental and RSM predicted PC concentrations were determined. The maximum experimental PC concentration was $6.9 \mathrm{mg} / \mathrm{g}$ biomass for $50 \%$ of wastewater, $680 \mathrm{~nm}$ and $40 \mu \mathrm{M}$ of salicylic acid. Similarly, the maximum RSM predicted PC concentration was $6.9 \mathrm{mg} / \mathrm{g}$ biomass. The minimum experimental and RSM predicted PC concentration was $4.7 \mathrm{mg} / \mathrm{g}$ biomass for $25 \%$ of wastewater, $440 \mathrm{~nm}$ and $80 \mu \mathrm{M}$ of salicylic acid. CCD of RSM for the maximum PC concentration was given in Table 5. 3D RSP and 2D contour plots related with wastewater concentration (v/v \%) (X1) and wavelength (nm) (X2) were given in Figure 4.

These figures explain how $\mathrm{X}_{1}$ and $\mathrm{X}_{2}$ affect $\mathrm{PC}$ concentrations. This 3D RSP figure had spherical shape. From -2 to 0 levels, wastewater and PC concentrations increased. On the other hand, from 0 to +2 levels, while wastewater increased, PC concentration decreased. From -2 to +2 levels, wavelength and PC concentrations increased. 3D RSP and 2D contour plots related with wastewater concentration (v/v \%) (X1) and salicylic acid $(\mu \mathrm{M})$ (X3) were given in Figure 5 . This figure had a uniform shape. This result showed that PC and wastewater concentrations increased from -2 to 0 levels. But, PC concentration decreased while salicylic acid concentration increased from -2 to 0 levels. Unlike, from 0 to +2 , PC concentration decreased while wastewater and salicylic acid concentrations increased. Interaction between wavelength and salicylic acid according to their 3D RSP and 2D contour plots was given in Figure 6.

Similarly, this figure had a uniform shape. From -2 to +2 , while wavelength and PC concentrations remarkably increased. Unlike, when salicylic acid

\begin{tabular}{|c|c|c|c|c|c|}
\hline Run No. & $\begin{array}{c}\text { Wastewater concentration } \\
\text { (X1) }(\mathrm{v} / \mathrm{v} \%)\end{array}$ & $\begin{array}{l}\text { Wavelength } \\
\text { (X2) (nm) }\end{array}$ & $\begin{array}{l}\text { Salicylic Acid } \\
(\mathrm{X} 3)(\mu \mathrm{M})\end{array}$ & $\begin{array}{l}\text { Experimental } \\
\text { (PC) } \mathrm{mg} / \mathrm{g}\end{array}$ & $\begin{array}{c}\text { RSM } \\
\text { Predicted (PC) } \mathrm{mg} / \mathrm{g}\end{array}$ \\
\hline 1. & 25 & 440 & 20 & 5.2 & 5.2 \\
\hline 2. & 25 & 440 & 80 & 4.7 & 4.7 \\
\hline 3. & 25 & 580 & 20 & 6.3 & 6.4 \\
\hline 4. & 25 & 580 & 80 & 5.8 & 5.8 \\
\hline 5. & 75 & 440 & 20 & 5.1 & 5.2 \\
\hline 6. & 75 & 440 & 80 & 4.8 & 4.8 \\
\hline 7. & 75 & 580 & 20 & 6.2 & 6.3 \\
\hline 8. & 75 & 580 & 80 & 5.7 & 5.8 \\
\hline 9. & 0 & 510 & 40 & 5.1 & 5.1 \\
\hline 10. & 100 & 510 & 40 & 5.2 & 5.1 \\
\hline 11. & 50 & 400 & 40 & 4.8 & 4.8 \\
\hline 12. & 50 & 680 & 40 & 6.9 & 6.9 \\
\hline 13. & 50 & 510 & 10 & 6.2 & 6.1 \\
\hline 14. & 50 & 510 & 160 & 5.4 & 5.4 \\
\hline 15. & 50 & 510 & 40 & 5.8 & 5.8 \\
\hline 16. & 50 & 510 & 40 & 5.7 & 5.8 \\
\hline 17. & 50 & 510 & 40 & 5.8 & 5.8 \\
\hline 18. & 50 & 510 & 40 & 5.7 & 5.8 \\
\hline 19. & 50 & 510 & 40 & 5.8 & 5.8 \\
\hline 20. & 50 & 510 & 40 & 5.8 & 5.8 \\
\hline 21. & 50 & 510 & 40 & 5.8 & 5.8 \\
\hline 22. & 50 & 510 & 40 & 5.7 & 5.8 \\
\hline 23. & 50 & 510 & 40 & 5.7 & 5.8 \\
\hline 24. & 50 & 510 & 40 & 5.8 & 5.8 \\
\hline
\end{tabular}
concentration increased, PC concentration drastically decreased. Probably, stress factors adversely affected

Table 5. CCD of RSM for the maximum phycocyanin concentration 

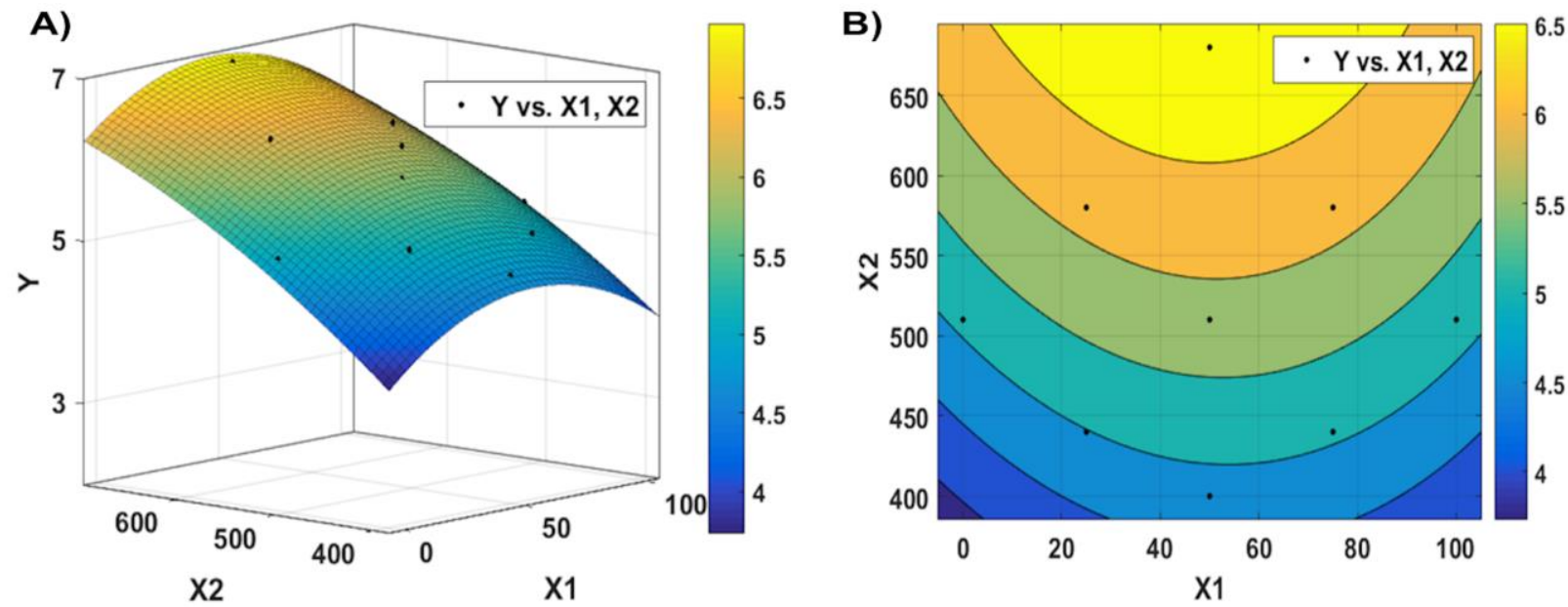

Figure 4. 3D RSM and 2D CPs for interaction effect of (A-B) wastewater concentration (v/v \%) (X1) and wavelength (nm) (X2) for PC concentration.
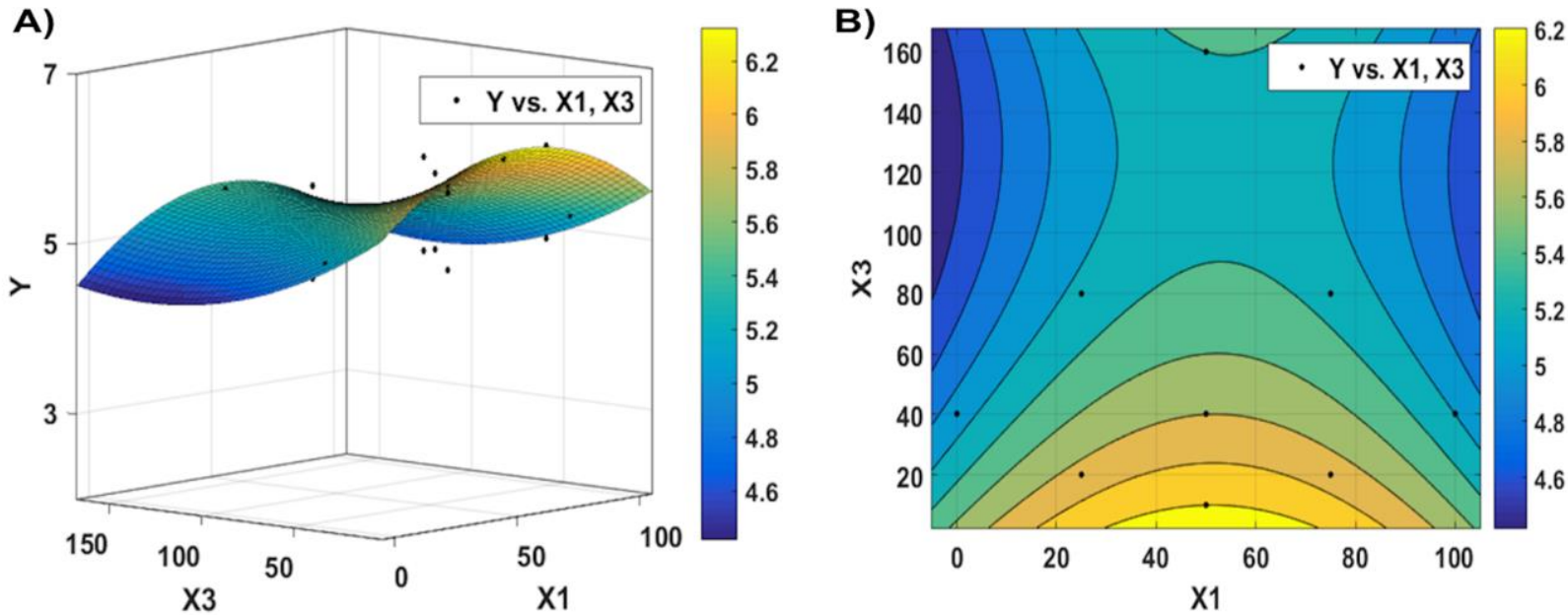

Figure 5. 3D RSM and 2D CPs for interaction effect of (A-B) wastewater concentration (v/v \%) (X1) and salicylic acid ( $\mu M)(X 3)$ for PC concentration.
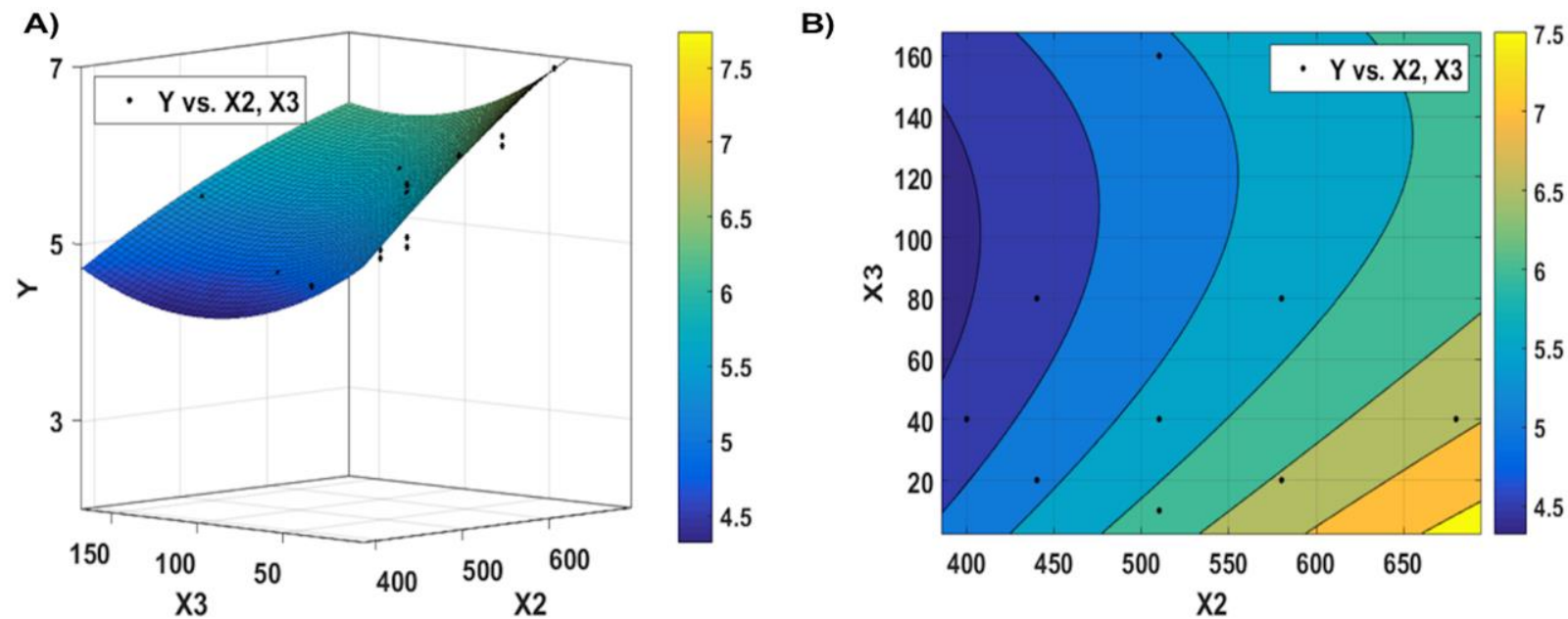

Figure 6. 3D RSM and 2D CPs for interaction effect of (A-B) Wavelength (nm) (X2) and Salicylic Acid ( $\mu$ M) (X3) for PC concentration.

PC concentration under these variables. In addition, while PC concentration increased in the long wavelengths such as yellow and red, it decreased in the short wavelengths such as purple and blue. These results were consistent with literature results. Parys et al. studied photosynthesis and pigment 
concentrations in Cyanidioschyzon merolae under the lights with various colors. Chlorophyll a $(5.26 \mathrm{nmol}$ $10^{-8}$ cells) and $\beta$-carotene (1.34 nmol $10^{-8}$ cells) had maximum concentrations in red light. However, chlorophyll a (3.47 nmol 10-8 cells) and $\beta$-carotene $\left(0.75 \mathrm{nmol} 10^{-8}\right.$ cells $)$ had minimum concentrations in white light.

On the other hand, while blue light had the highest PC concentration (1.25 nmol $10^{-8}$ cells), white light had the lowest PC concentration (0.72 nmol $10^{-8}$ cells) [42].

In another study, PC recovery from Anabaena cylindrica was studied with response surface methodology. Optimum solid-liquid ratio, extraction time and temperature were researched and four-fold recovery was obtained [43].

PC extraction method was optimized from Phormidium versicolor NCC-466 by RSM. The maximum PC concentration was $67.45 \mathrm{mg} / \mathrm{g}$ at solidwater ratio $1 / 2$, temperature $32.5^{\circ} \mathrm{C}$ and $\mathrm{pH} 7.2$. These parameters were used for the prevention of cadmium hepatoxicity [44]. PC from Spirulina platensis was produced in mixotrophic condition using RSM. The maximum PC concentration was maintained at light $\left(45.5 \mu \mathrm{mole} \mathrm{m}^{-2} \mathrm{~s}^{-1}\right)$, urea (114.74 $\left.\mathrm{mg} \mathrm{L}^{-1}\right)$ and molasses $\left(0.196 \mathrm{~L}^{-1}\right)[45]$.

PC purification from Arthrospira platensis was practiced by microwave-assisted technique. This technique depended on micro-extraction of liquids. The maximum PC yield was $86 \%$ at six min, $348 \mathrm{~K}$ and functional deep eutectic solvent volume of $650 \mu \mathrm{L}$ [46]. Deb et al. studied for PC production from
Anabaena variabilis using RSM. At $\mathrm{pH} 8.9, \mathrm{MgSO}_{4}$ (168.8 mg/L) and $\mathrm{NaHCO}_{3}(64.3 \mathrm{mg} / \mathrm{L})$, PC yield and content were $54.2 \mathrm{mg} / \mathrm{L}$ and $6.3 \% \mathrm{dcw}$, respectively [47].

Phycobiliprotein concentrations from Porphyridium purpureum were carried out using RSM. Light, temperature and nitrogen were selected as interaction parameters. The maximum phycobiliprotein content was $2.9 \% \mathrm{dw}$ at $30 \mathrm{~mol} \mathrm{~m}^{-2} \mathrm{~s}^{-1}$ of light, $10{ }^{\circ} \mathrm{C}$ [48].

In the literature, there are many studies about PC. PCs have distinguishable properties. The PCs with allophycocyanin are more stable than isolated ones [49]. Leptolyngbya sp. was researched for PC concentrations in extreme conditions such as higher light and temperature. PC concentration was 72.12 $\mathrm{mg} / \mathrm{g}$ biomass and biomass concentration $1.09 \mathrm{~g} / \mathrm{L} / \mathrm{d}$ at $40{ }^{\circ} \mathrm{C}$. This result was $45 \%$ higher than $A$. platensis. Also, the maximum biomass productivity was found at $300 \mu \mathrm{mol} \cdot \mathrm{m}^{-2} \cdot \mathrm{s}^{-1}[50]$.

Pulsed electric field was used for the production of PC from Arthrospira platensis. $1 \mu \mathrm{s}$ pulses at an electric field strength of $40 \mathrm{kV} \cdot \mathrm{cm}^{-1}$ were tested and the highest PC concentration was obtained [51]. Nostoc commune TUBT05 and Oscillatoria okeni TISTR8549 was investigated to obtain higher PC production.

Freezing and thawing methods were applied and these methods can be used for the extraction of biomass and PC production [52]. In another study, PC was carried out the effects of heavy metal cations on PC production in vitro and in silico. $\mathrm{Pb} 2^{+}$had the most significant effect on PC. The low concentration $\left(<2 \times 10^{-6} \mathrm{~mol} / \mathrm{L}\right)$ of it showed a negative effect. Also, the binding cites of

Table 6. ANOVA for quadratic model of phycocyanin concentration

\begin{tabular}{lcccccc}
\hline \multicolumn{7}{c}{ Phycocyanin Concentration (mg/g biomass ) } \\
\hline \multicolumn{1}{c}{ Source } & Df a & SS $^{\mathbf{b}}$ & MS $^{\mathbf{c}}$ & F-value & P-value & Significance \\
\hline Model & 9.0000 & 6.0857 & 0.6762 & 119.4397 & $<0.0001$ & Significant \\
Residual & 14.0000 & 0.0793 & 0.0057 & & & \\
Total & 23.0000 & 6.1650 & & & & \\
\hline
\end{tabular}

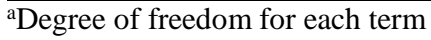

${ }^{\text {b }}$ Sum of Square for the regression model

${ }^{\mathrm{c}}$ Mean Squared error for each term

Table 7. ANOVA for estimated coefficients of the quadratic model of phycocyanin concentration

\begin{tabular}{|c|c|c|c|c|c|}
\hline \multicolumn{6}{|c|}{ Phycocyanin concentration (mg/ g biomass) } \\
\hline Source & Coefficient & StdErra & t value $^{b}$ & P value & Significance \\
\hline (Intercept) & -1.1573 & 0.95603 & -1.2106 & 0.2461 & \\
\hline $\mathrm{X}_{1}$ & 0.032062 & 0.0082559 & 3.8835 & 0.0016548 & Significant \\
\hline $\mathrm{X}_{2}$ & 0.017459 & 0.0031529 & 5.5373 & $7.3183 \times 10^{-5}$ & Very significant \\
\hline $\mathrm{X}_{3}$ & -0.0074868 & 0.006777 & -1.1047 & 0.2879 & \\
\hline $\mathrm{X}_{1} \mathrm{X}_{2}$ & $-1.4286 \times 10^{-5}$ & $1.5201 \times 10^{-5}$ & -0.93978 & 0.36327 & \\
\hline $\mathrm{X}_{1} \mathrm{X}_{3}$ & $2.1053 \times 10^{-5}$ & $3.4523 \times 10^{-5}$ & 0.60981 & 0.55176 & \\
\hline $\mathrm{X}_{2} \mathrm{X}_{3}$ & $-1.4085 \times 10^{-5}$ & $1.2384 \times 10^{-5}$ & -1.1374 & 0.27446 & \\
\hline $\mathrm{X}_{1} \mathrm{X}_{1}$ & $-2.5723 \times 10^{-4}$ & $2.2534 \times 10^{-5}$ & -11.415 & $1.7709 \times 10^{-8}$ & Very significant \\
\hline $\mathrm{X}_{2} \mathrm{X}_{2}$ & $-8.1803 \times 10^{-6}$ & $2.7717 \times 10^{-6}$ & -2.9514 & 0.010517 & Significant \\
\hline $\mathrm{X}_{3} \mathrm{X}_{3}$ & $5.306 \times 10^{-5}$ & $1.0188 \times 10^{-5}$ & 5.2079 & 0.00013265 & Very significant \\
\hline
\end{tabular}

Results is significant when $\mathrm{P}<0.05 \mathrm{R}^{2}=0.99, \mathrm{R}^{2}$ (adj) $=0.98, \mathrm{MSE}=0.0057$

aStandard error of the coefficients

$\mathrm{b} t$-statistic for each coefficient to test the null hypothesis

${ }^{c} p$-value for the $t$-statistic of the hypothesis test 
$\mathrm{Zn}^{2+}$ was located near chromophores in silico studies [53].

PC can be used for the medical proposes. PC from Spirulina platensis was purified and its anticancer, antidiabetic and anti-inflammatory effect were evaluated. Anticancer effect was $68 \%$ at $500 \mu \mathrm{g} / \mathrm{mL}$ of PC. It had antidiabetic effect at $250 \mu \mathrm{g} / \mathrm{mL}$ of PC. In addition, anti-inflammatory effect occurred at 500 $\mu \mathrm{g} / \mathrm{mL}$ of PC [54].

Extended usage of PC revealed the need of large scale production of PC. PC from Arthrospira platensis was produced in the outdoor photovoltaic photo bioreactor. Biomass productivity was $67 \%$ higher than raceway pond. PC productivity was $16.3 \mathrm{mg} / \mathrm{g} / \mathrm{d}$. and its purity was 1.2 .

These results emphasized that this PBR can be used for large scale PC production from Arthrospira platensis [55].

\subsection{ANOVA results for estimated coefficients and quadratic model of phycocyanin concentration}

ANOVA for quadratic model of PC concentration was calculated. All model was significant ( $p$ value < $0.0001)$. $F$ value was 119.4397. In addition, degrees of freedom (DF), sum of squares (SS) and mean square (MS) for PC concentration were given in Table 6.

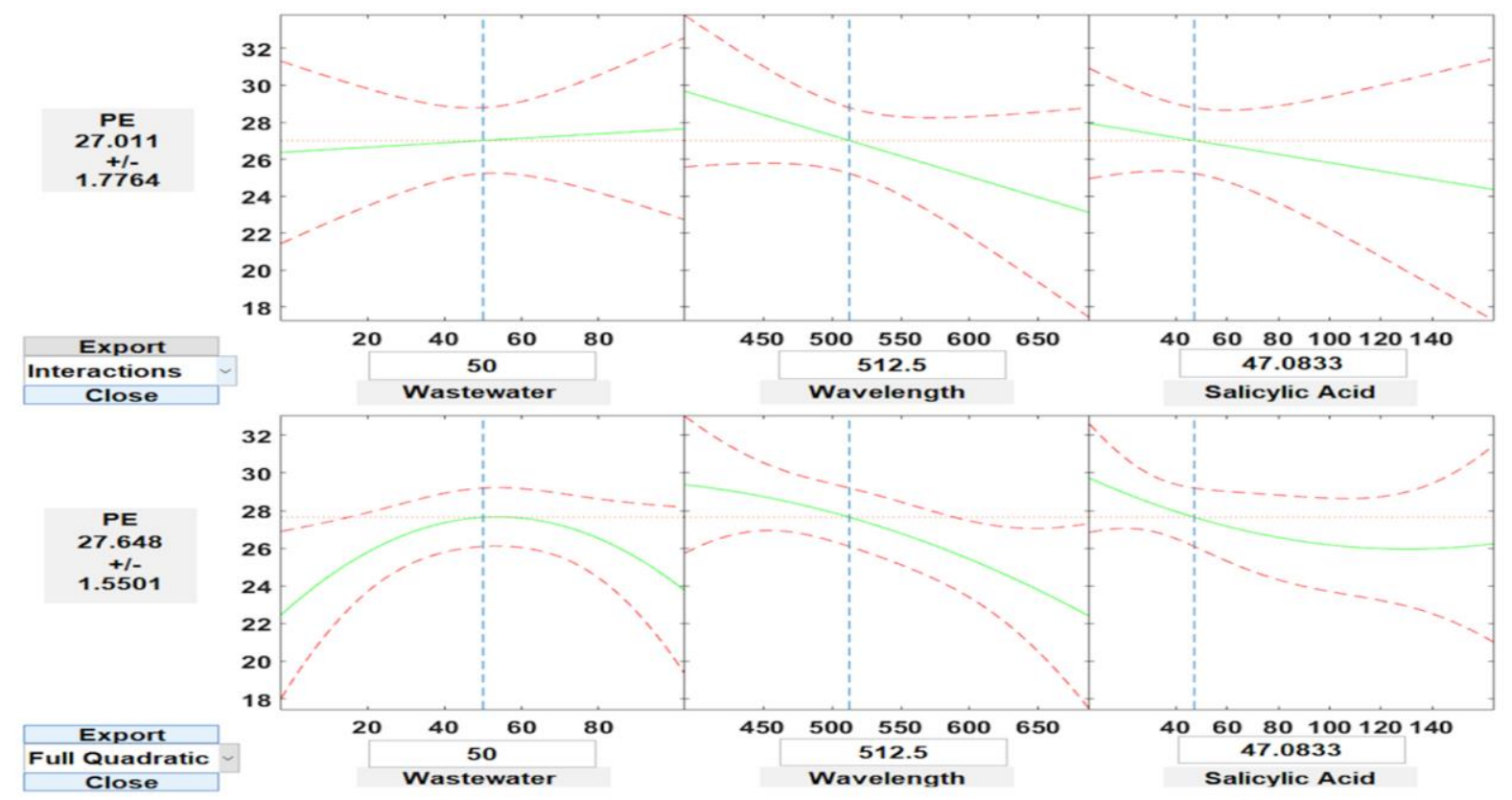

Figure 7. The input models related with full quadratic and interaction models on phycoerythrin concentration.

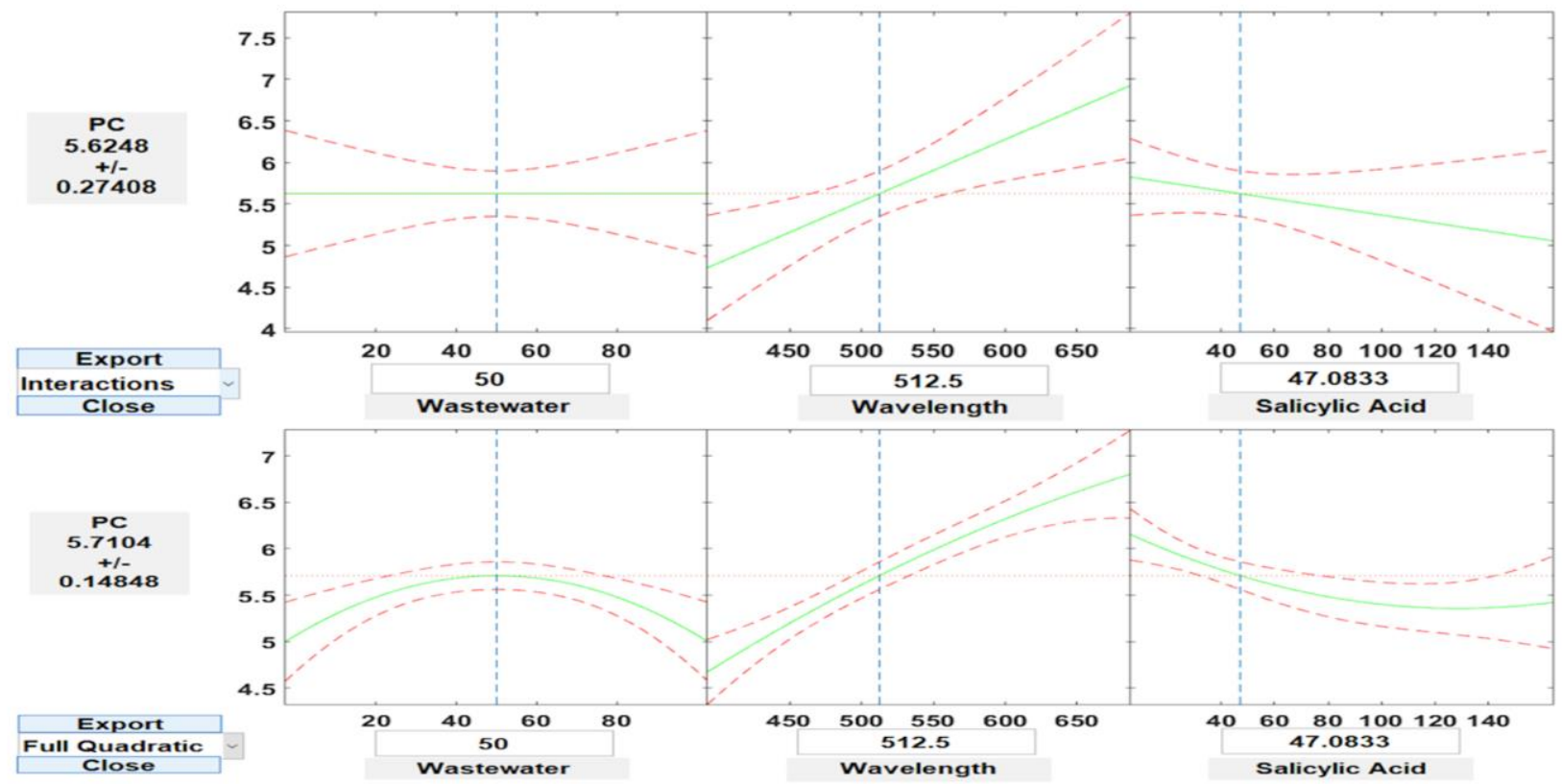

Figure 8. The input models related with full quadratic and interaction models on phycocyanin concentration. 
ANOVA for estimated coefficients of the quadratic model of PC concentration was estimated. Wastewater concentration was significant. In addition, wavelength was very important for PC concentration. Interaction effects for wastewater, wavelength and salicylic acid can be omitted according to ANOVA. However, squared effects of wastewater, wavelength and salicylic acid were very significant. In conclusion, three parameters remarkably affect PC concentration. ANOVA for estimated coefficients of the quadratic model of PC concentration in detail was given in Table 7.

\subsection{Interactive response surface modeling for the determination of maximum phycoerythrin and phycocyanin concentrations}

Interactive response surface modeling is a new method and it interactively researches onedimensional contours by means of multidimensional regression models. It shows a fitted regression model for a response.

In literature, there are few articles related with rstool. Quadratic model was used for the prediction of limit state function of the passive heat removal system. In their study, Ebrahimian et al. carried out two parameters such as air temperature and fouling factor and determined the effects of independent variables on heat removal capacity [56]. In another study, rstool was used to optimize a solar power tower. The parameters such as a baseline power purchase agreement, annual generation, cycle ramp, receiver starts and cycle starts were examined by rstool and the effects of each parameter on each response were determined [57].

In this study, we carried out interactive and full quadratic models to find maximum $\mathrm{PE}$ and $\mathrm{PC}$ concentrations. While full quadratic models had constant, linear, interaction, and squared terms, interaction maintains constant, linear and interaction terms. It does not have squared terms. The Root Mean Squared Error (rmse) value of PE was 0.7855 for full quadratic models. In addition to this, rmse value of PE was 1.6597 for interactive model. The maximum PE concentration was $27.011 \mathrm{mg} / \mathrm{g}$ biomass at $50 \%$ of wastewater, $512.5 \mathrm{~nm}$ and $47.0833 \mu \mathrm{M}$ of salicylic acid according to interaction model. Similarly, its maximum concentration was $27.648 \mathrm{mg} / \mathrm{g}$ biomass for $50 \%$ of wastewater, $512.5 \mathrm{~nm}$ and $47.0833 \mu \mathrm{M}$ of salicylic acid according to full quadratic model. The effect of squared terms was $0.637 \mathrm{mg} / \mathrm{g}$ biomass. This value approximately was equal to $2.5 \%$. In conclusion, the effect of squared terms can be ignored. These results support the ANOVA results. Interactive response surface modeling results for PE concentration were given in Figure 7. Also, we studied interactive and full quadratic models for PC concentration. The Root Mean Squared Error values of PC were 0.0752 and 0.2561 for interactive and full quadratic models, respectively. Interactive response surface modeling results for PE concentration were given in Figure 8.The maximum concentration of PC was $5.6248 \mathrm{mg} / \mathrm{g}$ biomass at $50 \%$ of wastewater, $512.5 \mathrm{~nm}$ and $47.0833 \mu \mathrm{M}$ of salicylic acid for interaction model. For full quadratic models, the highest PC concentration was $5.7104 \mathrm{mg} / \mathrm{g}$ biomass for $50 \%$ of wastewater, $512.5 \mathrm{~nm}$ and $47.0833 \mu \mathrm{M}$ of salicylic acid. The effect of squared terms was 0.0856 $\mathrm{mg} / \mathrm{g}$ biomass for PC. This value nearly was equal to $1.5 \%$. Like PE concentration, squared terms of PC can be ignored according to Interactive response surface modeling. However, these results are not in line with the ANOVA results. In conclusion, interactive response surface modeling cannot be used for squared terms of PC under wastewater, wavelength and salicylic acid parameters.

\section{Conclusion}

PE and PC are florescent pigments. They have a colorant role in the industry. While PE gives the red color, PC maintains the blue color. There are many sources from which these pigments are obtained. One of them is Porphyridium cruentum and it can be grown in various conditions. The variables such as wastewater, wavelength and salicylic acid are important for the production of these pigments. When squared terms of wastewater and salicylic acid were important for PE concentration, linear and squared terms of wastewater and wavelength were significant for PC concentration. Response Surface MethodologyCentral Composite Design (RSM-CCD) and rstool can be used for the production of maximum PE and PC from Porphyridium cruentum.

\section{Acknowledgment}

Author thanks Van-YYU-Faculty of Engineering for this study.

\section{Declaration of Ethical Code}

In this study, we undertake that all the rules required to be followed within the scope of the "Higher Education Institutions Scientific Research and Publication Ethics Directive" are complied with, and that none of the actions stated under the heading "Actions Against Scientific Research and Publication Ethics" are not carried out.

\section{References}

[1] Balti, R., Le Balc'h, R., Brodu, N., Gilbert, M., Le Gouic, B., Le Gall, S., Sinquin, C., Massé, A. 2018. Concentration and Purification of Porphyridium cruentum Exopolysaccharides by Membrane filtration at Various Cross- flow Velocities. Process Biochemistry, 74, 175-184.

[2] Bernaerts, T. M. M., Kyomugasho, C., Looveren, N. V., Gheysen, L., Foubert, I., Hendrickx, M. E., Loey, 
A.M. V. 2018. Molecular and Rheological Characterization of Different Cell Wall Fractions of Porphyridium cruentum. Carbohydrate Polymers, 195, 542-550.

[3] Aron, N. S. M., Khoo K. S., Chew, W. K., Veeramuthu, A., Chang, J., Show, P. L. 2020. Microalgae Cultivation in Wastewater and Potential Processing Strategies Using Solvent and Membrane Separation Technologies. Journal of Water Process Engineering, 101701.

[4] Pagels, F., Guedes, A.C., Amaro, H.M., Kijjoa, A. 2019. Phycobiliproteins from Cyanobacteria: Chemistry and Biotechnological Applications. Biotechnology Advances, 37, 422-443.

[5] Khatoon, H., Kok, L., Abdu, N., Mian, S., Begum, H., Banerjee, S., Endut, A. 2018. Effects of Different Light Source and Media on Growth and Production of Phycobiliprotein from Freshwater Cyanobacteria. Bioresource Technology, 249, 652-658.

[6] Tran, T., Lafarge, C., Winckler, P., Pradelles, R., Cayot, N., Loupiac, C. 2019. Ex situ and In situ Investigation of Protein/Exopolysaccharide Complex in Porphyridium cruentum Biomass Resuspension. Algal Research, 41, 101544.

[7] Hsieh-lo, M., Castillo, G., Ochoa-becerra, M. A., Mojica, L. 2019. Phycocyanin and Phycoerythrin: Strategies to Improve Production Yield and Chemical Stability. Algal Research, 42, 101600.

[8] Renugadevi, K., Nachiyar, C. V., Sowmiya, P., Sunkar, S. 2018. Antioxidant Activity of Phycocyanin Pigment Extracted from Marine Filamentous Cyanobacteria Geitlerinema $s p$ TRV57. Biocatalysis and Agricultural Biotechnology, 16, 237-242.

[9] Lauceri, R., Chini, G., Maserti, B., Torzillo, G. 2018. Purification of Phycocyanin from Arthrospira platensis by Hydrophobic Interaction Membrane Chromatography. Algal Research, 35, 333-340.

[10] Falkeborg, M. F., Roda-serrat, M. C., Burnaes, K. L., Nielsen, A. L. D. 2018. Stabilising Phycocyanin by Anionic Micelles. Food Chemistry, 239, 771-780.

[11] Arulselvan, P., Fard, M. T., Tan, W. S., Gothai, S., Fakurazi, S., Norhaizan, M. E., Kumar, S. S. 2016. Role of Antioxidants and Natural Products in Inflammation. Oxidative Medicine and Cellular Longevity, 5276130, 1-15.

[12] Ayas, Z. S., Fidan, A., Avsar, E. 2021. Examination of The Problems Experienced in Urban and Industrial Wastewater Treatment Facilities and Constructed Wetlands and Identification of Circumstances The Case of The Yozgat Province of Turkey. Fresenius Environmental Bulletin, 30(4), 4307-4316.

[13] Hena, S., Gutierrez, L., Crou, J. 2021. Removal of Pharmaceutical and Personal Care Products
(PPCPs) from Wastewater Using Microalgae: A review. Journal of Hazardous Materials, 403, 124041.

[14] Sher, F., Hanif, K., Rafey, A., Khalid, U., Zafar, A., Ameen, M., Lima, E. C. 2021. Removal of Micropollutants from Municipal Wastewater Using Different Types of Activated Carbons. Journal of Environmental Management, 278, 111302.

[15] Úbeda, B., Gálvez, J. Á., Michel, M., Bartual, A. 2017. Microalgae Cultivation in Urban Wastewater : Coelastrum cf . pseudomicroporum as a Novel Carotenoid Source and a Potential Microalgae Harvesting Tool. Bioresource Technology, 228, 210-217.

[16] Gupta, S., Pawar, S. B., Pandey, R. A. 2019. Current Practices and Challenges in Using Microalgae for Treatment of Nutrient Rich Wastewater from Agro-based Industries. Science of the Total Environment, 687, 1107-1126.

[17] Huang, G., Chen, F., Wei, D., Zhang, X., Chen, G. 2010. Biodiesel Production by Microalgal Biotechnology. Applied Energy, 87, 38-46.

[18] Suparmaniam, U., Kee, M., Uemura, Y., Wei, J., Teong, K., Hoong, S. 2019. Insights into The Microalgae Cultivation Technology and Harvesting Process for Biofuel Production: A review. Renewable and Sustainable Energy Reviews, 115, 109361.

[19] Lan, J. C., Raman, K., Huang, C., Chang, C. 2013. The Impact of Monochromatic Blue and Red LED Light upon Performance of Photo Microbial Fuel Cells (PMFCs) using Chlamydomonas reinhardtii Transformation F5 as Biocatalyst. Biochemical Engineering Journal, 78, 39-43.

[20] Iasimone, F., Panico, A., Felice, V. De, Fantasma, F., Iorizzi, M., Pirozzi, F. 2018. Effect of Light Intensity and Nutrients Supply on Microalgae Cultivated in Urban Wastewater: Biomass Production, Lipids Accumulation and Settle Ability Characteristics. Journal of Environmental Management, 223, 1078-1085.

[21] He, Q., Yang, H., Wu, L., Hu, C. 2015. Effect of Light Intensity on Physiological Changes, Carbon Allocation and Neutral Lipid Accumulation in Oleaginous Microalgae. Bioresource Technology, 191, 219-228.

[22] Bazdar, E., Roshandel, R., Yaghmaei, S., Mahdi, M. 2018. The Effect of Different Light Intensities and Light/Dark Regimes on The Performance of Photosynthetic Microalgae Microbial Fuel Cell. Bioresource Technology, 261, 350-360.

[23] Raj, J. V. A., Bharathiraja, B., Vijayakumar, B., Arokiyaraj, S., Iyyappan, J. 2019. Biodiesel Production from Microalgae Nannochloropsis oculata Using Heterogeneous Poly Ethylene 
Glycol (PEG) Encapsulated $\mathrm{ZnOMn}^{2+}$ Nanocatalyst. Bioresource Technology, 282, 348352.

[24] Lu, D., Liu, X., Apul, O.G., Zhang, L., Ryan, D.K., Zhang, X. 2019. Optimization of Biomethane Production from Anaerobic Co-digestion of Microalgae and Septic Tank Sludge. Biomass and Bioenergy, 127, 105266.

[25] Zou, X., Xu, K., Wen, H., Xue, Y., Zhao, S., Xie, W. 2019. A Novel Method to Recover Microalgae by Compound Buoyant-bead Flotation. Separation and Purification Technology, 211, 658-666.

[26] Onumaegbu, C., Alaswad, A., Rodriguez, C., Olabi, A. 2019. Modelling and Optimization of Wet Microalgae Scenedesmus quadricauda Lipid Extraction Using Microwave Pre-treatment Method and Response Surface Methodology. Renewable Energy, 132, 1323-1331.

[27] Andersen, R. A. 2005. Algal Culturing Techniques. 1st Edition. Elsevier Academic press, USA, 487s.

[28] OECD, 2010. OECD Guidelines for the Testing of Chemicals (Technical Report 209). Activated Sludge, Respiration Inhibition Test (Carbon and Ammonium Oxidation). Guideline 16. https://www.oecdilibrary.org/content/publicati on/9789264070080-en (Access Date: 05.05.2020).

[29] Zouboulis, A. I., Gkotsis, P. K., Zamboulis, D. X., Mitrakas, M. G. 2017. Application of powdered activated carbon for membrane fouling control in a pilot-scale MBR system. Water Science and Technology, 75(10), 2350-2357.

[30] Onay, M. 2018. Bioethanol production via different saccharification strategies from $H$. tetrachotoma ME03 grown at various concentrations of municipal wastewater in a flatphotobioreactor. Fuel, 239, 1315-1323.

[31] Coward, T., Fuentes-grünewald, C., Silkina, A., Oatley-radcliffe, D. L., Llewellyn, G., Lovitt, R. W. 2016. Utilising Light-emitting Diodes of Specific Narrow Wavelengths for the Optimization and Co-production of Multiple High-value Compounds in Porphyridium purpureum. Bioresource Technology, 221, 607-615.

[32] Beer, S., Eshel, A. 1985. Determining Phycoerythrin and Phycocyanin Concentrations in Aqueous Crude Extracts of Red Algae. Australian Journal of Marine and Freshwater Research, 36(6), 785-792.

[33] Mishra, S. K., Shrivastav, A., Maurya, R. R., Patidar, S. K., Haldar, S., Mishra, S. 2012. Effect of Light Quality on the C-phycoerythrin Production in Marine Cyanobacteria Pseudanabaena sp. Isolated from Gujarat Coast, India. Protein Expression and Purification, 81, 5-10.
[34] Dumay, J., Clément, N., Morançais, M., Fleurence, J. 2013. Optimization of Hydrolysis Conditions of Palmaria palmata to Enhance R-phycoerythrin Extraction. Bioresource Technology, 131, 21-27.

[35] Pereira, T., Barroso, S., Mendes, S., Amaral, R. A., Dias, J. R., Baptista, T., Saraiva, J. A., Alves, N. M., Gil, M. M. 2020. Optimization of Phycobiliprotein Pigments Extraction from Red Algae Gracilaria gracilis for Substitution of Synthetic Food Colorants. Food Chemistry, 321, 126688.

[36] Gargouch, N., Karkouch, I., Elleuch, J., Elkahoui, S., Michaud, P., Abdelka, S., Laroche, C., Fendri, I. 2018. Enhanced B-phycoerythrin Production by The Red Microalga Porphyridium marinum: A Powerful Agent in Industrial Applications. International Journal of Biological Macromolecules, 120, 2106-2114.

[37] Mittal, R., Raghavarao, K. S. M. S. 2018. Extraction of R-Phycoerythrin from Marine Macro-algae, Gelidium pusillum, Employing Consortia of Enzymes. Algal Research, 34, 1-11.

[38] Martínez, J. M., Delso, C., Álvarez, I., Raso, J. 2019. Pulsed Electricfield Permeabilization and Extraction of Phycoerythrin from Porphyridium cruentum. Algal Research, 37, 51-56.

[39] Munier, M., Jubeau, S., Wijaya, A., Morançais, M., Dumay, J., Marchal, L., Jaouen, P., Fleurence, J. 2014. Physicochemical Factors Affecting The Stability of Two Pigments: R-phycoerythrin of Grateloupia turuturu and B-phycoerythrin of Porphyridium cruentum. Food Chemistry, 150, 400-407.

[40] Zhao, P., Wang, X., Niu, J., He, L., Gu, W., Xie, X., Wu, M., Wang, G. 2020. Agar Extraction and Purification of R-phycoerythrin from Gracilaria tenuistipitata and Subsequent Wastewater Treatment by Ulva prolifera. Algal Research, 47, 101862.

[41] Afreen, S., Fatma, T. 2018. Extraction, Purification and Characterization of Phycoerythrin from Michrochaete and Its Biological Activities. Biocatalysis and Agricultural Biotechnology, 13, 84-89.

[42] Parys, E., Krupnik, T., Kułak, I., Kania, K., Romanowska, E. 2021. Photosynthesis of The Cyanidioschyzon merolae Cells in Blue, Red, and White Light. Photosynthesis Research, 147, 6173.

[43] Sintra, T. E., Bagagem, S. S., Ghazizadeh, F., Fernandes, A., Martins, M., Macário, I. P. E., Pereira, J. L., Gonçalves, F. J. M. 2021. Sequential Recovery of C-phycocyanin and Chlorophylls from Anabaena cylindrica. Separation and Purification Technology, 255, 117538.

[44] Gammoudi, S., Athmouni, K., Nasri, A., Diwani, N., Grati, I., Belhaj, D., Bouaziz-ketata, H., El, A., Ayadi, 
H. 2019. Optimization, Isolation, Characterization and Hepatoprotective Effect of a Novel Pigmentprotein Complex (phycocyanin) Producing Microalga: Phormidium versicolor NCC-466 Using Response Surface Methodology. International Journal of Biological Macromolecules, 137, 647656.

[45] Setyoningrum, T. M., Nur, M. M. A. 2015. Optimization of C-phycocyanin Production from $S$. platensis Cultivated on Mixotrophic Condition by Using Response Surface Methodology. Biocatalysis and Agricultural Biotechnology, 4, 603-607.

[46] Rathnasamy, S. K., Rajendran, D., Balaraman, H. B., Viswanathan, G. 2019. Functional Deep Eutectic Solvent-based Chaotic Extraction of Phycobiliprotein Using Microwave-assisted Liquid-liquid Micro-extraction from Spirulina (Arthrospira platensis) and Its Biological activity Determination. Algal Research, 44, 101709.

[47] Deb, D., Mallick, N., Bhadoria, P. B. S. 2021. Engineering Culture Medium for Enhanced Carbohydrate Accumulation in Anabaena variabilis to Stimulate Production of Bioethanol and Other High-value Co-products under Cyanobacterial Refinery Approach. Renewable Energy, 163, 1786-1801.

[48] Guihéneuf, F., Stengel, D. B. 2015. Towards the Biorefinery Concept: Interaction of Light, Temperature and Nitrogen for Optimizing The Co-production of High-value Compounds in Porphyridium purpureum. Algal Research, 10, 152-163.

[49] Wang, G. C., Zhou, B. C., Tseng, C. K. 1997. Spectroscopic Properties of The C-phycocyaninallophycocyanin Conjugate and The Isolated Phycobilisomes from Spirulina platensis. Photosynthetica, 34(1), 57-65.

[50] Schipper, K., Fortunati, F., Oostlander, P. C., Muraikhi, M. Al, Mohammed, H., Jabri, S. J. Al, Wijffels, R. H., Barbosa, M. J. 2020. Production of
Phycocyanin by Leptolyngbya sp. in Desert Environments. Algal Research, 47, 101875.

[51] Akaberi, S., Krust, D., Müller, G., Frey, W., Gusbeth, C. 2020. Impact of Incubation Conditions on Protein and C-Phycocyanin Recovery from Arthrospira platensis Post-pulsed Electric field Treatment. Bioresource Technology, 306, 123099.

[52] Chittapun, S., Jonjaroen, V., Khumrangsee, K., Charoenrat, T. 2020. C-phycocyanin Extraction from Two Freshwater Cyanobacteria by Freeze Thaw and Pulsed Electric Field Techniques to Improve Extraction Efficiency and Purity. Algal Research, 46, 101789.

[53] Chi, Z., Hong, B., Tan, S., Wu, Y., Li, H., Lu, C. 2020. Impact Assessment of Heavy Metal Cations to The Characteristics of Photosynthetic Phycocyanin. Journal of Hazardous Materials, 391, 122225.

[54] Prabakaran, G., Sampathkumar, P., Kavisri, M., Moovendhan, M. 2020. Extraction and Characterization of Phycocyanin from Spirulina platensis and Evaluation of Its Anticancer, Antidiabetic and Antiinflammatory Affect. International Journal of Biological Macromolecules, 153, 256-263.

[55] Nwoba, E. G., Parlevliet, D. A., Laird, D. W., Alameh, K., Moheimani, N. R. 2020. Outdoor Phycocyanin Production in A Standalone Thermally-insulated Photobioreactor. Bioresource Technology, 315, 123865.

[56] Ebrahimian, M., Pirouzmand, A., Rabiee, A. 2020. Time-invariant Reliability Assessment for A Passive Heat Removal System Based on FORM Methodology with A New Approach for Finding The Design Point. Annals of Nuclear Energy, 147, 107740.

[57] Wagner, M. J., Hamilton, W. T., Newman, A., Braun, R., Dent, J., Diep, C. 2018. Optimizing Dispatch for A Concentrated Solar Power Tower. Solar Energy, 174, 1198-1211. 